\title{
Remediation of Petroleum Oil Contaminated Soil by Using Organic Fertilizer
}

\author{
Shailesh N Gadhvi* \\ Sardar Patel University, Vallabh Vidya Nagar, India \\ *Corresponding Author: Dr. Shailesh N Gadhvi, Sardar Patel University, Vallabh Vidya Nagar, India.
}

Received: August 16, 2019; Published: September 26, 2019

DOI: 10.31080/ASAG.2019.03.0665

\begin{abstract}
Experiment was conducted at Agricultural farm to remediate crude oil contaminated soil with organic and inorganic fertilizers. For this thirty six pots were prepared and filled with $2.5 \mathrm{~kg}$ crude oil contaminated soils $(0-20 \mathrm{~cm})$. The soils were contaminated with $150 \mathrm{ml}$ crude oil and mixed with $150 \mathrm{gm}$ of poultry manure and 75gm of NPK fertilizer. Herbal plant like Indian Tulsa was planted in each pot. Results showed that this application reduced soil Total hydrocarbon abour 87.0\%. By using mixture of Inorganic and organic fertilizer mixtures are effective in the restoration of crude oil contaminated soils.
\end{abstract}

Keywords: Hydro Carbon Contamination; Petroleum Product and Crude Oil; NPK Fertilizer; Poultry Waste Manure; Remediation; Herbal Plant

\section{Introduction}

Pollution caused by petroleum and its side stream product is the most prevalent problem for nearby area of refinery. Since commercial exploration of petroleum has big contribution in growth of any country, petroleum industries has continuously grown in. However this industries has led to the pollution of land and water in different ways. Petroleum is a complex mixture of aliphatic, naphthenic and, aromatic hydrocarbons, and smaller proportions of heteroatom compounds, such as sulfur, nitrogen, and oxygen. Crude oil also having traces amount of organometallic complexes containing nickel and vanadium. These organometallic compounds are problematic during crude oil refining because it had adverse effect on various catalyst that used for refining of crude [1]. Invariably, oil spillage damages the soil, water and both plants and animals. Its pollution renders soils unproductiveness for years after spillage, also reducing the growth performance of plants by deteriorating fertility of soil [2]. Therefore, plant growth and establishment, and rejuvenation of polluted sites can serve as indicators for soil recovery [3]. Several methods are being adopted to remove oil wastes and derivatives from soil and water. These include physical methods), chemical method, and biological methods out of them several physical methods are spray, vapor extraction, solidification and stabilization. While example of chemical methods are photo oxidation, dissolution, detergent cleaning and on other hand example of biological methods are bioremediation. All these methods are applied for treatment of contaminated sites depends on the kind of contamination in each case. Phytoremediation is the one of the methodology in which plants are used to remove or render harmful pollutant from soil [4].The application of some particular plant for remediation of soil that contaminated with petroleum hydrocarbon is one of the cost effective and eco- friendly approach [5]. Schnoor [6] reported that phytoextraction is more effective with vigorously growing plants that are easily harvested and which accumulate large concentration of contaminants in harvestable form. Tithonia seedlings were able to absorb lead and cadmium in polluted soils, and contents in the root were more than contents in the shoot. The lead and cadmium contents in the shoot compared to the root were about $54 \%$ and $30 \%$ respectively [7]. Isitekhale., et al. [8] reported net remediation of $75.45 \%$ and $77.51 \%$ using vigorously growing sweet potato variety on crude oil contaminated soil; even with higher concentrations, growth was further sustained. Transformation of contaminants may occur outside the plant in the rhizosphere, inside the plant or sorbed to the leaf surface (photolysis) [9]. Sweet potato (Ipomeabatata L.). Ogboghodo., et al. [10] reported that adding chicken manure to soil that contaminated with crude oil resulting degradation of $75 \%$ of hydrocarbon in the soil within two weeks, and suggested that the use of chicken manure to stimulate crude oil degradation in the soil could be one of the most result oriented environmentally friendly ways of combating petroleum hydrocarbon pollution in the natural ecosystem. Eneje., et al. [11] reported that addition of organic materials such as poultry waste and plant waste singly or in combination to improve the chemical properties ( $\mathrm{pH}, \mathrm{OC}$, total nitrogen, available $\mathrm{P}, \mathrm{Ca}, \mathrm{K}$, and $\mathrm{Mg}$ ) of the oil polluted soil not only that it will enhance the solubility and removal of these crude oil contaminants, improving oil biodegradation rates. Fertilizer (NPK) served as a good supplement for the growth of the petroleum utilizing bacteria in oil - polluted Journal of Environment and Earth Science www.iiste.org ISSN 2224 - 3216 (Paper) ISSN 2225 - 0948 (Online) Vol. 3, No.7, 2013117 soils [12]. Leo and Iruka [13] reported that by using sufficient quantity of inorganic NPK fertilizer on the oil contaminated soil, it helps in the restoration of the carbon to 
nutrient ratios to the optimum required to stimulate and sustain microbial activity, adjustment of the soil $\mathrm{pH}$ to $6.0-6.5$ by the addition of lime and also the stimulation. Obire and Akinde [14] reported that nutrient supplementation of oil - polluted with poultry droppings as organic nutrient source in particular is beneficial for maize growth and it also enhances both biodegradation of oil and soil recovery. Poultry manure additions to soil giving very positive results in plant nutrients addition, enhancement of soil biological value and enhancement of crop growth and yield [15-17]. Therefore the aim behind this experiment is to employ poultry manure and/or N: P: K 16:16:16) fertilizer for the remediation of crude oil contaminated soil in order to enhance plant growth and yield.

\section{Study area}

The experiment was conducted at the coastal area of Gujarat state in India Gujarat state has a humid climate characterized by one rainy season between June and August and one dry season lasting from March to May. The temperature of Gujrat state is characterized of tropical climate with mean temperature of about 36.00C. Relative humility is fairly high especially during the months of June to November.

\section{Materials and Methods}

The experiment was conducted by taking random sample of Soil ( $5 \mathrm{~kg}$ ) in to perforated polyethylene bags ( $6 \mathrm{~kg}$ capacity). The experiment consisted of twelve polyethylene bags per replicate, giving a total of thirty six bags for the experiment. The soils were contaminated with $50 \%$ of crude oil. The soils were then allowed to equilibrate for 2 weeks; after a 14 days $2.5 \mathrm{~kg}$ of poultry manure and $2.5 \mathrm{~kg}$ of Gir breed cow shit was homogenously mixed and kept for next two week after giving enough equilibrium time Tithonia seedlings planted or sweet potato vine with two nodes was planted in each polyethylene bag. Poultry manure was collected from layers kept in chicken cages, it contain feces and urine that dropped down by chicken. The droppings were air dried for 6 months in order to ensure complete breakdown. The growth of Tithonia seedlings flower plant or sweet potato was monitored to $12^{\text {th }}$ week. Some important parameter that determine quality of soil samples were tested in laboratory before and after contamination. Particle size distribution was determined by using the hydrometer method [18], soil pH was measured in a 1:1 ratio by taking soil and water by using glass electrode $\mathrm{pH}$ meter [19], organic carbon was done by wet dichromate acid oxidation method [20], total nitrogen was determined by the micro Kjeldahl method [21]. Available phosphorus was extracted with Bray II solution and determined by the molybdenum blue method on the Technicon auto - analyzer as modified by Olsen and Sommers [22], Potassium and sodium were determined with flame emission photometer while calcium and magnesium were determined with automatic adsorption spectrophotometer [23]. Total hydrocarbon content was analyzed by using a methylene chloride extraction; gas chromatography (GC) analyzing technique [24] the amount of crude oil lost from the soil was determined as the amount of crude oil added to the soil minus that in the soil at the time of analysis.

\section{Results and Discussion}

Soil Physical - Chemical Properties of the crude oil is measured, the physical - chemical properties of the soil that used for experiments also measured before crude oil contamination. The experimental soil having lower content of phosphorus, nitrogen and potassium but with marginal contents of magnesium and calcium. The surface sand of soil should be enables to percolate of the crude oil. Portray farm waste as manure and NPK fertilizer in combination added to crude oil contaminated soil.

\begin{tabular}{|l|c|}
\hline Specific gravity $\left(\mathrm{g} / \mathrm{cm}^{3}\right)$ & 0.79 \\
\hline Viscosity at $38^{\circ} \mathrm{C}$ & 0.25 \\
\hline Gas oil ratio & 88.20 \\
\hline Carbon \% & 82.50 \\
\hline Hydrogen \% & 11.80 \\
\hline Sulphur \% & 1.32 \\
\hline Nitrogen \% & 0.36 \\
\hline Oxygen \% & 0.50 \\
\hline Metals $(\mathrm{mg} / \mathrm{kg})$ & \\
\hline Iron & 49.60 \\
\hline Nickel & 2.80 \\
\hline Vanadium & 0.40 \\
\hline Copper & 3.0 \\
\hline Zinc & 3.15 \\
\hline Lead & 0.90 \\
\hline Cadmium & 0.30 \\
\hline Cobalt & 0.80 \\
\hline
\end{tabular}

Table 1: Chemical properties of the crude oil used for the study.

After keeping this mixture for more than fifteen days in open climate with wetted form few piece of sweet potato or Tithonian was planted. Potato tuber weight increased significantly with the application of $3 \mathrm{t} \mathrm{pm} / \mathrm{ha}+300$ and $400 \mathrm{~kg} \mathrm{NPK} / \mathrm{h}$. The very low yield obtained from the unfertilized soil is due to the harmful effects of crude oil to plants growth and yield. However, yield obtained from crude contaminated soil that treated with manure and fertilizer mixture was 6 t/ha [24]. Asuquo., et al. [26] observed that increases in organic carbon in crude oil contaminated soil create an initial scarcity of nitrogen. This nitrogen deficiency in an oil - soaked soil, effect on bacterial growth it retards the growth of bacteria also deficiency in certain nutrients like phosphorus which may be growth - rate limiting factor [27].

Total hydrocarbon content ranged from nil to $138.96 \mathrm{mg} / \mathrm{kg}$ after the soil was contaminated with $300 \mathrm{ml}$ of crude oil. It was noted that the various treatments were effective in hydrocarbon removal. Net hydrocarbon remediation ranged from 111.96 to $262.86 \mathrm{mg} /$ $\mathrm{kg}$. The highest hydrocarbon removal was obtained by the application of $4 \mathrm{t} \mathrm{pm} / \mathrm{ha}+200 \mathrm{~kg} \mathrm{NPK} / \mathrm{ha}$ and $6 \mathrm{t} \mathrm{pm} / \mathrm{ha}+400 \mathrm{~kg} \mathrm{NPK} / \mathrm{ha}$. This resulted in 87.62 and $86.97 \%$ net remediation respectively. All above observation shows that higher quantity of poultry manure in combination used with moderate to reach NPK fertilizer is very much effective for remediation of soils that contaminated 


\begin{tabular}{|l|c|}
\hline Crude oil pH $\left(\mathrm{H}_{2} \mathrm{O}\right)$ & 6.80 \\
\hline Total N $(\mathrm{g} / \mathrm{kg})$ & 1.02 \\
\hline Total C $(\mathrm{g} / \mathrm{kg})$ & 10.88 \\
\hline Cations $(\mathrm{c} \mathrm{mol} / \mathrm{kg})$ & 3.84 \\
\hline Total $\mathrm{Mg}(\mathrm{g} / \mathrm{kg})$ & 2.40 \\
\hline $\mathrm{Na}(\mathrm{g} / \mathrm{kg})$ & 0.33 \\
\hline $\mathrm{K}(\mathrm{g} / \mathrm{kg})$ & 0.08 \\
\hline Particle size $(\mathrm{g} / \mathrm{kg})$ Sand & 941.00 \\
\hline Particle size $(\mathrm{g} / \mathrm{kg})$ Silt & 16.00 \\
\hline Particle size $(\mathrm{g} / \mathrm{kg})$ clay & 43.00 \\
\hline
\end{tabular}

Table 2: Physico-chemical properties of the experimental soil.

with crude oil. Residual characteristics of poultry manure could further lead to more hydrocarbon removal. Residual characteristics of poultry manure have been documented $[8,15]$. Addition of organic materials such as poultry and green manure either alone or in combination use full to improve the chemical properties $(\mathrm{pH}$, organic carbon, total nitrogen, available $\mathrm{P}, \mathrm{Ca}, \mathrm{K}$, and $\mathrm{Mg}$ ) of the oil contaminated soil. Thus, improve crude oil biodegradation rates [28-34].

\section{Conclusion}

Sweet potato or Tithonia a vigorously growing plant can reduce the level of crude oil in crude oil contaminated soil to tolerable limit as observed in this study. Remediation capacity of the growing potato or Tithonia could also be enhanced through manure and fertilizer mixtures. Thus, application of $4 \mathrm{t} \mathrm{pm} / \mathrm{ha}+200 \mathrm{~kg} \mathrm{NPK} /$ ha and $6 \mathrm{t} \mathrm{pm} / \mathrm{ha}+400 \mathrm{~kg} \mathrm{NPK} / \mathrm{ha}$ to crude oil polluted soils will enhance crude oil remediation, soil nutrient addition and growth of plants.

\section{Bibliography}

1. Head IM., et al. "Biological activity in the deep subsurface and the origin of heavy oil". Nature 426 (2003): 344-352.

2. Dale P., et al. Growth and metal accumulation ability of plants on soil polluted with $\mathrm{Cu}, \mathrm{Zn}$ and Pb Ekologija 1 (2006): 48-52.

3. Obilo PO and Ogunyemi S. "The use of maize as an indicator crop and in the remediation of farmland laden with heavy metals as a result of crude oil pollution". Discovery and Innovation 17.3-4 (2005): 180-185.

4. Merkl N. "Phytoremediation of petroleum-contaminated soil". Margraf Publisher Weikershim (2005): 12.

5. Eman A Diab. "Phytoremediation of oil contaminated Desert soil using the Rhizosphere effects, Department of plant Ecology and ranges, Environmental Pollution Research unit; DRC". Egypt Global Journal of Environmental Research 2.2 (2008): 66-73.

6. Schnoor JL. "Technology evaluation report: phytoremediation of soil and groundwater". GWRTAC Series (2002).
7. Egberongbe RK. “Can Tithoniadiversifolia. Hemsl, a gray, a pantropic invasive weed species, cleanup spent lubricating oil polluted soils". Global Journal of Environmental Sciences (2010).

8. Isitekhale HHE. "Effect of poultry manure and NPK fertilizer on the performance of tomato and on soil properties". Ph. D Thesis. Ambrose Alli University, Ekpoma, Nigeria (2010): 1-163.

9. Trapp S and Karlson U. "Aspects of phytoremediation of organic pollutants". Journal of soil sediments (2001): 1-7.

10. Ogboghodo I., et al. "The effects of application of poultry manure to crude oil polluted soils on maize growth and soil properties". Environ Monit and Assess 96.1-3 (2004): 153-161.

11. Eneje RC., et al. "Amelioration of chemical properties of crude oil contaminated soil using compost from Calapoigoniummucunoides and poultry manure". International Research Journal of Agricultural Science and Soil Science 2.6 (2012): 246-251.

12. Adoki A., et al. "The effects of amendments on biodegradation of crude petroleum by sediment bacteria from Bonny River". Estuary Africa Journal Ecology 37.3 (2007): 258-256.

13. Leo C Osuji and I Nwoye. "Petroleum and Environmental Chemistry Research Group, Department of Industrial and Pure Chemistry: University of Port Harcourt". African Journal of Agricultural Research 2.7 (2007): 318-324.

14. Obire 0 and Akinde. "Comparative study of the efficiency of cow dung and poultry manure as nutrient alternative sources in bioremediation of oil polluted soil, Niger Delta". Biologia 5.2 (2006): 82-91.

15. Isitekhale HHE and Osemwota IO. "Residual effects of poultry manure and NPK fertilizer on nutrient contents and uptake by tomato in the forest and derived savanna soils of Edo State". Nigerian Journal of Soil Science 20.2 (2010a): 17-25.

16. Isitekhale HHE and Osemwota IO. "Residual effects of poultry manure and NPK fertilizer on soil physical properties in the forest and derived savanna soils of Edo State". Nigerian Journal of Soil Science 20.2 (2010b).

17. Isitekhale HHE., et al. "Poultry manure and NPK fertilizer application and their residual effects on the yield and yield components of tomato (Lycopersiconesculentum. Mill) in two distinct ecological zones of Central Southern Nigeria". IOSR Journal of Agriculture and Veterinary Science (IOSR-JAVS). 3.2 (2013): 40-47.

18. Okalebo JR., et al. "Laboratory methods of soil and plant analysis". A working manual.2 nd edition. Sacred Africa, Nairobi, Kenya (2002): 22-77.

19. MaClean EO. Soil pH and lime requirement in Black, C, A. (Ed): Methods in soil analysis chemical and microbiological properties part II- American Society of Agronomy, Maidison, Wiscousin USA (1982): 927-932. 
20. Nelson and Sommer LE. "Total carbon, organic carbon, organic matter". In page A.L Miller, R.H and Keeney, D.R (edition) method of soil analysis part 2. Agronomy monography, second edition (1982): 539-579.

21. Bremner JM., et al. "Methods of Soil Analysis part II 2nd edition". American society of Agronomy, Madison Wiscousin, in Anderson J.M and Ingram J.S. (eds) Tropical soil biology and fertility. A Handbook of Methods. Inf. Press Eyasham (1982): 10-85.

22. Olson and Sommers LE. Phosphorus in Page A.L., Miller, R.H and Keeney, D.R (eds). Method of soil analysis Part II 2ND edition. America society of Agronomy Madison, Wiscousin USA (1992): 402-403.

23. Anderson JM and Ingram JS. "Tropical soil biology and fertility. A handbook of methods. Information Press Eynsham". Journal of Environment and Earth Science 3.7 (1993): 119.

24. Villalobos M., et al. "An improved gravimetric method to determine total petroleum hydrocarbons in contaminated soils". Water, Air, and Soil Pollution 194.1-4 (2008): 1-4.151-161.

25. Mutandwa E. "Performance of tissue cultured sweet potatoes among small holder farmers in Zimbabwe". Ag Bioforum (2008): 48-57.

26. Asuquo FE., et al. "Effects of Quaiboe crude oilcontamination on germination and growth of Okra (Abelmoschusesculentus. L) and fluted pumpkin (Telfairiaoccidentalis L) Proc. Of the 27th Annual Conf. of the soil science of Nig. University of Calabar (2001): 5-9.

27. Atlas RM and Bartha R. "Degradation and mineralization of petroleum in seawater: limitation by nitrogen and phosphorus". Biotechnology and Bioengineering 14.3 (2005): 309-318.

28. EADP. Edo Agricultural Development Programme weather main station, Irrua, Esan West L.G.A. Edo State, Nigeria (1995).

29. Frank H and Althoen SC. "Statistics concepts and applications". Low price (ed). Cambridge University Press (1995): 539.

30. Njoku KL., et al. "Phytoremediation of crude oil contaminated soil: the effect of growth Glycine max on the physico-chemistry and crude oil content of soil". Nature and Science 7.10 (2009).

31. Nwinyi SC., et al. "Studies on optimum fertilizer requirement of sweet potato". Proceedings of 5 th Annual conference soil sci. society of Nigeria, Kaduna October. 20-24 (1987): 120-126.

32. Obazuaye E. "Mapping and classification of some soils in Ambrose Alli University Teaching and Research farm, Ekpoma, Nigeria". MSc thesis. Department of Soil Science. 6-10. Journal of Environment and Earth Science 3.7 (2013) (2009): 120.
33. Okoh AI. "Biodegradation of Bonny light crude oil in soil microcosm by some bacteria strains isolated from crude oil flow stations saver pits in Nigeria". African Journal of Biotechnology 2.5 (2003): 104-108.

34. Thomas GW. "Exchangeable Cation". In page, A.L et al (eds) methods of soil analysis". Part 2, Agronomy monograph, a second edition, ASA and SSSA, Madison, wiscosin (1982): 159165.

\section{Volume 3 Issue 10 October 2019} (C) All rights are reserved by Shailesh N Gadhvi. 